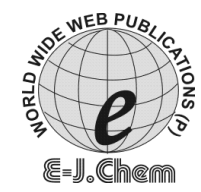

http://www.e-journals.net

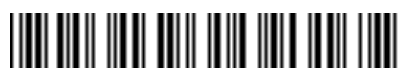

ISSN: 0973-4945; CODEN ECJHAO

E-Journal of Chemistry

Vol. 4, No. 3, pp. 428-433, July 2007

\title{
Synthesis and Biological Evaluation of Substituted Thiophenyl Derivatives of Indane-1, 3-dione
}

\author{
D. GILES*, M. S. PRAKASH, and K. V. RAMSESHU \\ K. M. College of Pharmacy, Madurai. Tamilnadu, India. \\ sahayagiles@yahoo.com
}

Received 18 January 2007; Accepted 2 March 2007

\begin{abstract}
Indane-1, 3-dione (1) synthesized by condensation of diethyl phthalate and ethyl acetate in presence of sodium ethoxide gave sodium salt of ester derivative, which on neutralization in presence of sulphuric acid afford 1. Various thiols where converted to their respective disulphide (3) which on treatment with $\mathbf{1}$ gave 2-substituted thio phenyl derivatives (4a-g) of $\mathbf{1}$. The synthesized compounds were characterized on the basis of I.R and $\mathrm{H}^{1} \mathrm{NMR}$. Synthesized compounds (4a-g) were investigated for their anticoagulant, analgesic, anti-inflammatory, antifungal, antibacterial and anticancer activities. Some of the synthesized compounds have shown moderate activities.
\end{abstract}

Keywords: Indane-1, 3-dione, Diazotisation, Anti cancer, Anti-inflammatory, Antibacterial

\section{Introduction}

Indane-1,3-dione ${ }^{1-3}$ constitute a unique group of compounds due to its 1,3-dicarbonyl nature, having specific physiochemical property which offers wide scope for studies in problems of theoretical organic chemistry particularly on the basis of tautomerism, dual reactivity. It has a wide range of biological activity covering anticoagulant, bactericidal, fungicidal, neurotropopic etc. Aromatic amines where diazotized ${ }^{4}$ and treated with potassium ethyl xanthate which was prepared by the reaction of carbon disulphide, ethanol in potassium hydroxide, gave aromatic thiols (2). It was oxidized using potassium ferri cyanide in sodium hydroxide afford disulphide (3) in good yield. Indane-1, 3-dione ${ }^{5,6}$ on treatment with $\mathbf{3}$ using potassium carbonate in dry acetone gave substituted derivatives of indane-1, 3-dione (4a-g).

\section{Experimental}

Thin layer chromatography was used to find out the completion of the reaction and purity of the compounds synthesized. Melting points were determined by open end capillary tubes by using thiel's tube containing liquid paraffin and were uncorrected. IR spectra in $\mathrm{KBr}$ were 
recorded on a Jasco-410 model FTIR spectrophotometer, ${ }^{1} \mathrm{H}$ NMR spectra were recorded on Brucker spectrophotometer $(300 \mathrm{MHz})$ in $\mathrm{CDCl}_{3}$ using TMS as an internal standard (chemical shifts are expressed in $\delta$, ppm). The purity of the compounds were checked on silica gel-G coated plates by using chloroform and ethyl acetate (7:3) as the eluent and observed in UV light. All the synthesized compounds (Scheme 1) gave satisfactory elemental analyses.

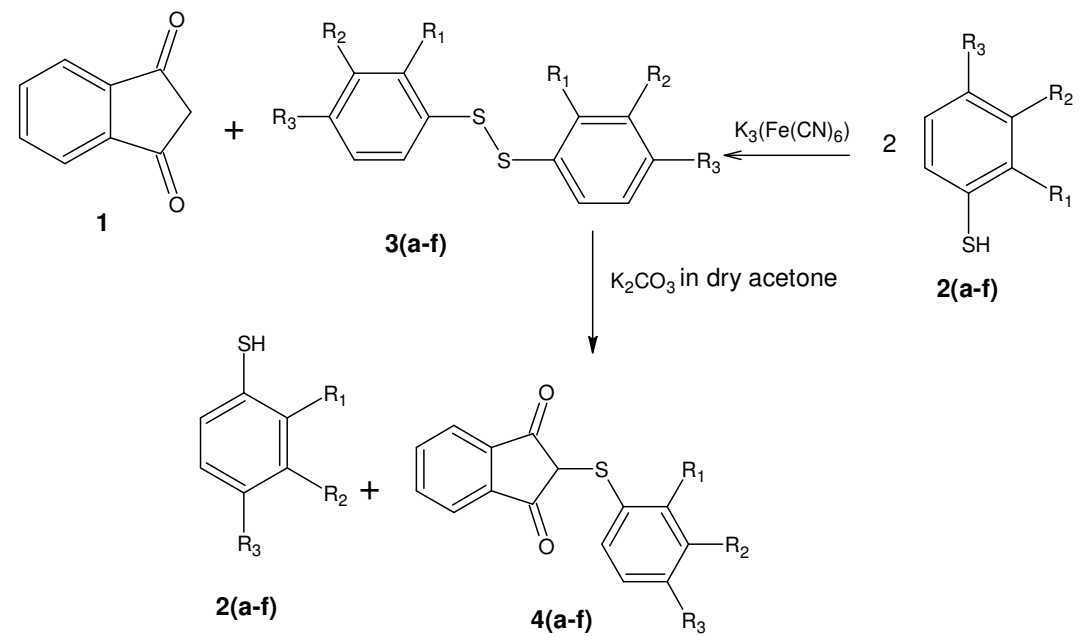<smiles>COC(=O)c1ccc(CSSCc2ccccc2)cc1</smiles>

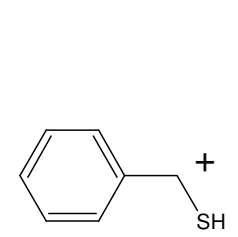

$2 \mathrm{~g}$

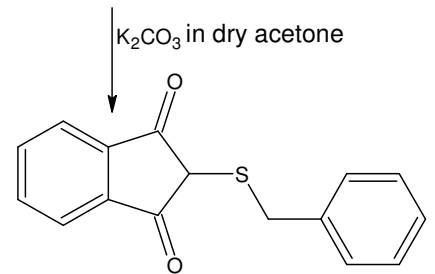

4g

\begin{tabular}{c|ccc} 
& $\mathrm{R}_{1}$ & $\mathrm{R}_{2}$ & $\mathrm{R}_{3}$ \\
\hline $\mathrm{a}$ & $\mathrm{CH}_{3}$ & $\mathrm{H}$ & $\mathrm{H}$ \\
$\mathrm{b}$ & $\mathrm{H}$ & $\mathrm{H}$ & $\mathrm{CH}_{3}$ \\
$\mathrm{c}$ & $\mathrm{H}$ & $\mathrm{Cl}$ & $\mathrm{H}$ \\
$\mathrm{d}$ & $\mathrm{H}$ & $\mathrm{H}$ & $\mathrm{Cl}$ \\
$\mathrm{e}$ & $\mathrm{H}$ & $\mathrm{H}$ & $\mathrm{OCH}_{3}$ \\
$\mathrm{f}$ & $\mathrm{H}$ & $\mathrm{H}$ & $\mathrm{H}$
\end{tabular}

Scheme 1 


\section{General procedure for synthesis of substituted dithiodibenzene (3a-f)}

To a stirred solution of substituted thiophenol $(0.02 \mathrm{~mole})$ in $10 \%$ sodium hydroxide $(20 \mathrm{~mL})$ aqueous solution of potassium ferricyanide $(6.6 \mathrm{~g}, 0.02 \mathrm{~mol}$ in $50 \mathrm{~mL}$ of water) was added slowly. The reaction mixture was kept for $1 \mathrm{~h}$ with constant stirring. The separated bis substituted phenyl disulphide was filtered. The product is recrystallised using ethanol.

\section{Synthesis of 1,1'-[dithiobis(methylene)]dibenzene (3g)}

Benzyl thiol $(2 \mathrm{~mL})$ was dissolved in 1:1 methanol in glacial acetic acid $(50 \mathrm{~mL})$ was allowed to run slowly into a stirred solution of Iron III chloride $(\mathbf{2 g})$ in methanol $(12 \mathrm{~mL})$ and glacial acid $(5 \mathrm{~mL})$. After 15 minutes it was diluted with water $(100 \mathrm{~mL})$. The oil that separate milky at first latter solidifies when kept at $0{ }^{\circ} \mathrm{C}$ recrystallised form methanol

\section{General procedure for the synthesis of 2-substituted indane-1,3-dione (4a-g)}

To a solution of indane-1, 3-dione $(1.5 \mathrm{~g}, 0.01 \mathrm{M})$ in dry acetone $(20 \mathrm{~mL})$, anhydrous potassium carbonate $(\mathbf{5 g})$ and synthesized disulphide $(\mathbf{3 a - g})(0.01 \mathrm{M})$ were added and the contents of the flask were refluxed for $4 \mathrm{~h}$. The resulting solution was filtered and the residue was washed with acetone $(3 \mathrm{X} 25 \mathrm{~mL})$ filtered and concentrated, the residue was treated with ice water and recrystallised from methanol.

\section{2-[(2-Methyl phenyl)thio]-indane-1,3-dione (4a)}

Melting point $=201^{\circ} \mathrm{C}$, yield $=62 \%$, IR $(\mathrm{KBr}) 3058(\mathrm{C}-\mathrm{H}), 1714$ and $1671(\mathrm{C}=\mathrm{O}), 1554$ $(\mathrm{C}=\mathrm{C}),{ }^{1} \mathrm{H}$ NMR 7.1 -7.33 (m, $\left.4 \mathrm{H}, \mathrm{ArH}\right), 7.61-7.93$ (m, $\left.4 \mathrm{H}, \mathrm{ArH}\right), 2.4\left(\mathrm{~s}, 3 \mathrm{H}, \mathrm{CH}_{3}\right)$ 1.6(m, $1 \mathrm{H}, \mathrm{CH})$. Anal. Calculated for $\mathrm{C}_{16} \mathrm{H}_{12} \mathrm{O}_{2} \mathrm{~S}$ is $\mathrm{C}(71.62 \%), \mathrm{H}(4.51 \%), \mathrm{O}(11.93 \%)$, and $\mathrm{S}$ $(11.95 \%)$ and found to be $\mathrm{C}(71.85 \%), \mathrm{H}(4.99 \%), \mathrm{O}(12.08 \%)$, and S (12.25\%)

\section{2-[(4-Methyl phenyl)thio]-indane-1,3-dione (4b)}

Melting point $=211^{\circ} \mathrm{C}, \quad$ yield $=58 \%$, IR $(\mathrm{KBr}) 3052(\mathrm{C}-\mathrm{H}), 1718$ and $1668(\mathrm{C}=\mathrm{O}), 1561$ $(\mathrm{C}=\mathrm{C}),{ }^{1} \mathrm{H}$ NMR $7.25-7.42(\mathrm{~m}, 4 \mathrm{H}, \mathrm{ArH}), 7.65-7.85(\mathrm{~m}, 4 \mathrm{H}, \mathrm{ArH}), 2.2\left(\mathrm{~s}, 3 \mathrm{H}, \mathrm{CH}_{3}\right)$ 1.5(m, $1 \mathrm{H}, \mathrm{CH})$.Anal. Calculated for $\mathrm{C}_{16} \mathrm{H}_{12} \mathrm{O}_{2} \mathrm{~S}$ is $\mathrm{C}(71.62 \%), \mathrm{H}(4.51 \%), \mathrm{O}(11.93 \%)$, and $\mathrm{S}(11.95 \%)$ and found to be C (72.05\%), H (5.02\%), O (12.15\%), and S (12.35\%)

\section{2-[(3-Chlorophenyl)thio]-indane-1,3-dione (4c)}

Melting point $=157^{\circ} \mathrm{C}$, yield $=62 \%$, IR $(\mathrm{KBr}) 3066(\mathrm{C}-\mathrm{H}), 1712$ and $1670(\mathrm{C}=\mathrm{O}), 1552(\mathrm{C}=\mathrm{C}),{ }^{1} \mathrm{H}$ NMR 7.33 -7.48 (m, $4 \mathrm{H}, \mathrm{ArH}), 7.68-7.86(\mathrm{~m}, 4 \mathrm{H}, \mathrm{ArH}), 1.5(\mathrm{~m}, 1 \mathrm{H}, \mathrm{CH})$. Anal. Calculated for $\mathrm{C}_{15} \mathrm{H}_{9} \mathrm{Cl} \mathrm{O}_{2} \mathrm{~S}$ is $\mathrm{C}(62.39 \%), \mathrm{H}(3.14 \%), \mathrm{Cl}(12.28 \%), \mathrm{O}(11.08 \%)$, and $\mathrm{S}(11.11 \%)$ and found to be $\mathrm{C}(63.52 \%), \mathrm{H}(3.52 \%), \mathrm{Cl}(13.11 \%), \mathrm{O}(11.58 \%)$, and $\mathrm{S}(12.01 \%)$

\section{2-[(4-Chlorophenyl)thio]-indane-1,3-dione (4d)}

Melting point $=195^{\circ} \mathrm{C}$, yield=66\%, IR $(\mathrm{KBr}) 3079(\mathrm{C}-\mathrm{H}), 1749$ and $1714(\mathrm{C}=\mathrm{O}), 1556(\mathrm{C}=\mathrm{C})$, ${ }^{1} \mathrm{H}$ NMR 7.36 -7.49 (m, $\left.4 \mathrm{H}, \mathrm{ArH}\right), 7.70-7.86$ (m, $\left.4 \mathrm{H}, \mathrm{ArH}\right), 1.4(\mathrm{~m}, 1 \mathrm{H}, \mathrm{CH})$.Anal. Calculated for $\mathrm{C}_{15} \mathrm{H}_{9} \mathrm{Cl} \mathrm{O}_{2} \mathrm{~S}$ is $\mathrm{C}(62.39 \%), \mathrm{H}(3.14 \%), \mathrm{Cl}(12.28 \%), \mathrm{O}(11.08 \%)$, and $\mathrm{S}(11.11 \%)$ and found to be $\mathrm{C}(63.45 \%), \mathrm{H}(3.44 \%), \mathrm{Cl}(13.05 \%), \mathrm{O}(11.44 \%)$, and $\mathrm{S}(12.06 \%)$

\section{2-[(4-Methoxyphenyl)thio]-indane-1,3-dione (4e)}

Melting point $=191^{\circ} \mathrm{C}$, yield=61\%, IR $(\mathrm{KBr}) 3072(\mathrm{C}-\mathrm{H}), 1712$ and $1675(\mathrm{C}=\mathrm{O}), 1552(\mathrm{C}=\mathrm{C})$, 1168 (C-O), ${ }^{1} \mathrm{H}$ NMR 6.9 -7.49 (m, 4 H, ArH), 7.77 -7.96 (m, 4 H, ArH), 3.7 (s, 3H, $\left.\mathrm{CH}_{3}\right) 1.5(\mathrm{~m}$, 
1H, CH).Anal. Calculated for $\mathrm{C}_{16} \mathrm{H}_{12} \mathrm{O}_{3} \mathrm{~S}$ is $\mathrm{C}(67.59 \%), \mathrm{H}(4.25 \%), \mathrm{O}(16.88 \%)$, and $\mathrm{S}$ (11.21\%) and found to be $\mathrm{C}(68.22 \%), \mathrm{H}(4.62 \%), \mathrm{O}(17.22 \%)$, and $\mathrm{S}(12.22 \%)$

\section{2-(Phenylthio)-indane-1,3-dione (4f)}

Melting point $=218^{\circ} \mathrm{C}, \%$ yield=68, IR $(\mathrm{KBr}) 3066(\mathrm{C}-\mathrm{H}), 1714$ and $1670(\mathrm{C}=\mathrm{O}), 1548$ $(\mathrm{C}=\mathrm{C}),{ }^{1} \mathrm{H}$ NMR 7.1 -7.33 (m, $\left.5 \mathrm{H}, \mathrm{ArH}\right), 7.51$-8.02 (m, $\left.4 \mathrm{H}, \mathrm{ArH}\right), 1.2(\mathrm{~m}, 1 \mathrm{H}, \mathrm{CH})$. Anal. Calculated for $\mathrm{C}_{15} \mathrm{H}_{10} \mathrm{O}_{2} \mathrm{~S}$ is $\mathrm{C}(70.84 \%), \mathrm{H}(3.96 \%), \mathrm{O}(12.58 \%)$, and $\mathrm{S}(12.61 \%)$ and found to be $\mathrm{C}(71.51 \%), \mathrm{H}(4.29 \%), \mathrm{O}(12.88 \%)$, and $\mathrm{S}(13.22 \%)$

\section{2-(Benzylthio)-indane-1,3-dione (4g)}

Melting point $=177^{\circ} \mathrm{C}, \%$ yield=66, IR $(\mathrm{KBr}) 3066(\mathrm{C}-\mathrm{H}), 2958(\mathrm{C}-\mathrm{H}) 1714$ and $1670(\mathrm{C}=\mathrm{O})$, $1554(\mathrm{C}=\mathrm{C}),{ }^{1} \mathrm{H}$ NMR $7.5-7.8$ (m, $\left.5 \mathrm{H}, \mathrm{ArH}\right), 7.9$-8.2 (m, $\left.4 \mathrm{H}, \mathrm{ArH}\right), 1.3$ (s, 2H, CH2), 1.2(m, $1 \mathrm{H}, \mathrm{CH})$.Anal. Calculated for $\mathrm{C}_{16} \mathrm{H}_{12} \mathrm{O}_{2} \mathrm{~S}$ is $\mathrm{C}(71.62 \%), \mathrm{H}(4.51 \%), \mathrm{O}(11.93 \%)$, and $\mathrm{S}$ (11.95\%) and found to be $\mathrm{C}(72.12 \%), \mathrm{H}(4.95 \%), \mathrm{O}(12.55 \%)$, and $\mathrm{S}(12.02 \%)$

\section{Results and Discussion}

The biological activity of the synthesized compounds is presented in Table 1 .

\section{Anticoagulant activity}

Indane-1, 3-dione processes mainly used as anticoagulant activity which was carried out for $\mathbf{1}$, 4a-g using the procedure adopted by Miller ${ }^{7}$. The time required to clot formation was measured among these substitution of methyl $(\mathbf{4 a}, \mathbf{b})$, Chloro $(\mathbf{4 c}, \mathbf{d})$ group and hydrogen $(\mathbf{4 g})$ in thiophenyl group showed good anticoagulant activity when compared to indane-1, 3-dione

\section{Antibacterial activity}

Compounds 1,4a-g were evaluated for Invitro antibacterial activity ${ }^{8}$ against S.aureus and $P$. vulgaris. Most of the compounds exhibited significant activity against S.aureus, which is shown in Table 1. Compounds $\mathbf{4 f}, \mathbf{4 c}, \mathbf{4 d}$ and $\mathbf{4 e}$ having phenyl, meta and 4 chloro phenyl and 4 methoxy phenyl group attached to indane-1,3-dione by sulphur processes good activity when compared to other synthesized derivatives. But when compared to standard it is less active.

\section{Antifungal activity}

Compounds 1,4a-g were evaluated for antifungal activity ${ }^{8}$ against Candida albicans. Most of the compounds exhibited significant activity against Candida albicans. Compound $\mathbf{4 f}$, processes good antifungal activity when compared to other derivatives of indane-1,3-dione.

\section{Analgesic activity}

Analgesic activity ${ }^{9}$ was carried out for 1,4a-g compound using hot plate method. Jump response was taken as end point. The reaction time after and before administration of drug was calculated. Maximum activity was obtained at 45 minutes. Compounds $\mathbf{4 a}, \mathbf{4 b}, \mathbf{4 c}$, and 4d processes good analgesic activity when compared with other derivatives. But it is less active than standard.

\section{Anti-inflammatory activity}

Anti-inflammatory ${ }^{9}$ activity was carried out using carriageenan induced paw oedema in rats using plethysmograph. Maximum activity was obtained as 120 minutes for compounds $\mathbf{4 a}, \mathbf{4 b}, \mathbf{4 f}$ and $\mathbf{4 g}$. 


\section{Anti cancer activity}

In vitro anti cancer ${ }^{10}$ studies for $\mathbf{1 , 4 a - g}$ were carried out by short term incubation method using DAL cells. The dead cells were determined by using trypan blue and cell count was done using haemocytometer. Considerable activity was observed for the $\mathbf{4 e}$ and $\mathbf{4 g}$.

In vivo studies for $\mathbf{1 , 4 a - g}$ were carried out using mice. The DAL cells were introduced into peritoneal cavity of mice for tumour development. The cells were aspired aseptically from tumour developed mice during log phase and cell count was done using trypan blue exclusion method. Anti cancer activity was not observed for the compounds.

Table 1. Biological activity of the synthesized compounds.

\begin{tabular}{|c|c|c|c|c|c|c|c|}
\hline \multirow[b]{2}{*}{ Compounds } & \multirow[b]{2}{*}{ 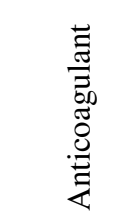 } & \multirow[b]{2}{*}{ 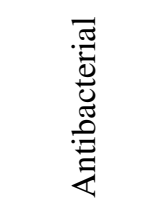 } & \multirow[b]{2}{*}{ 总 } & \multirow[b]{2}{*}{ 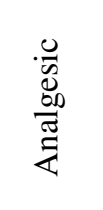 } & \multirow{2}{*}{ 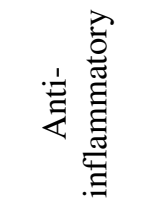 } & \multicolumn{2}{|c|}{ Antitumour } \\
\hline & & & & & & 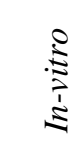 & 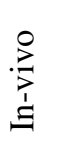 \\
\hline Standard drug & $\underset{* * *}{\text { Heparin }}$ & $\underset{* * *}{\operatorname{Amikacin}}$ & $\underset{* * *}{\text { Griseofulvin }}$ & $\begin{array}{c}\text { Penta- } \\
\text { zocin } \\
* * *\end{array}$ & $\begin{array}{l}\text { Indo- } \\
\text { methacin } \\
* * *\end{array}$ & \multicolumn{2}{|c|}{$\begin{array}{c}\text { 5-Flurouracil } \\
* * *\end{array}$} \\
\hline Indane-1,3-dione(1) & $*$ & $*$ & $*$ & $* *$ & $*$ & $*$ & $*$ \\
\hline $\begin{array}{l}\text { 2-[(2-Methyl } \\
\text { phenyl)thio]-indane- } \\
\text { 1,3-dione (4a) }\end{array}$ & $* *$ & $*$ & $* *$ & $* *$ & $* * *$ & $*$ & $*$ \\
\hline $\begin{array}{l}\text { 2-[(4-Methyl } \\
\text { phenyl)thio]-indane- } \\
\text { 1,3-dione (4b) }\end{array}$ & $* *$ & $*$ & $* *$ & $* *$ & $* * *$ & $*$ & $*$ \\
\hline $\begin{array}{l}\text { 2-[(3-Chloro } \\
\text { phenyl)thio]-indane- } \\
\text { 1,3-dione }(\mathbf{4 c})\end{array}$ & $* *$ & $* *$ & $* *$ & $* *$ & $*$ & $*$ & $*$ \\
\hline $\begin{array}{l}\text { 2-[(4-Chloro } \\
\text { phenyl)thio]-indane- } \\
\text { 1,3-dione }(\mathbf{4 d})\end{array}$ & $* *$ & $* *$ & $* *$ & $* *$ & $*$ & $*$ & $*$ \\
\hline $\begin{array}{l}\text { 2-[(4-Methoxy } \\
\text { phenyl)thio]-indane- } \\
\text { 1,3-dione (4e) }\end{array}$ & $*$ & $* *$ & $*$ & $*$ & $*$ & $* *$ & $*$ \\
\hline $\begin{array}{l}\text { 2-(Phenylthio)- } \\
\text { indane-1,3-dione (4f) }\end{array}$ & $* *$ & $*$ & $* * *$ & $*$ & $* * *$ & $* *$ & $*$ \\
\hline $\begin{array}{l}\text { 2-(Benzylthio)- } \\
\text { indane-1,3-dione (4g) }\end{array}$ & $*$ & $* *$ & $* *$ & $*$ & $* * *$ & * & $*$ \\
\hline
\end{tabular}




\section{Acknowledgments}

The authors are thankful to Prof. P Ramesh, School of Chemistry, M K University Madurai for his helpful discussion during the research work.

\section{References}

1. Meena S, Shankar D, Ramseshu K V and Giles D, Indian J. Chem, 2006, 45B, 1572-1575.

2. Dubers G, Organic and Physical Chemistry of 1,3-Indane diones and related compounds, 1975, 10, 121-143.

3. Durden J A, Biocidal activity of Indane-1,3-dione and related compounds, 1975, 10, 144-171.

4. Horning Gilman and Blatt, Organic Synthesis, Collective Volume III, 809-811.

5. Furniss B S, Hannaford A J, Rogers V, Smith P W G and Tatchell A R, Vogel's Text book of Organic Chemistry, 1978, 588, 860.

6. Hilgetag G and Martin A, Preparative Organic Chemistry, 635-636, 732, 795.

7. Miller J L, Clinical diagnosis and management by laboratory methods $765-769,17^{\text {th }}$ Ed. Saunders Company W B, Philadelphia.

8. Mackie and Mcartney Practical Medical Microbiology, Vol II $13^{\text {th }}$ Ed., 260.

9. Kulkarni S K, Hand book of Experimental Pharmacology, 125,128.

10. Mary K T, Cancer letters, 1994, 81, 53-57. 


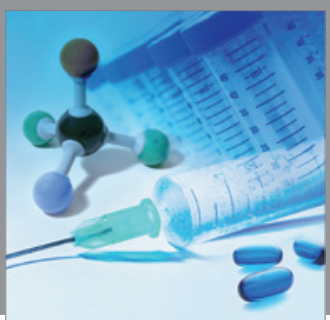

International Journal of

Medicinal Chemistry

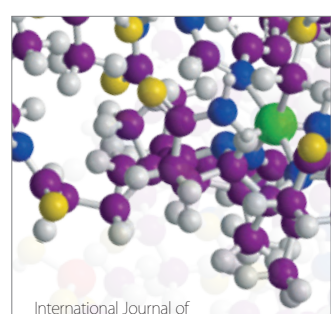

Carbohydrate Chemistry

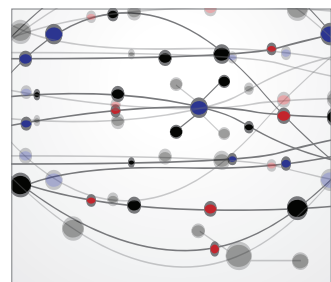

The Scientific World Journal
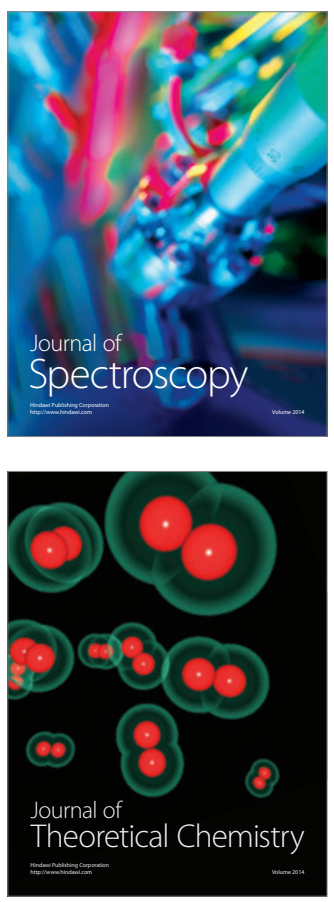
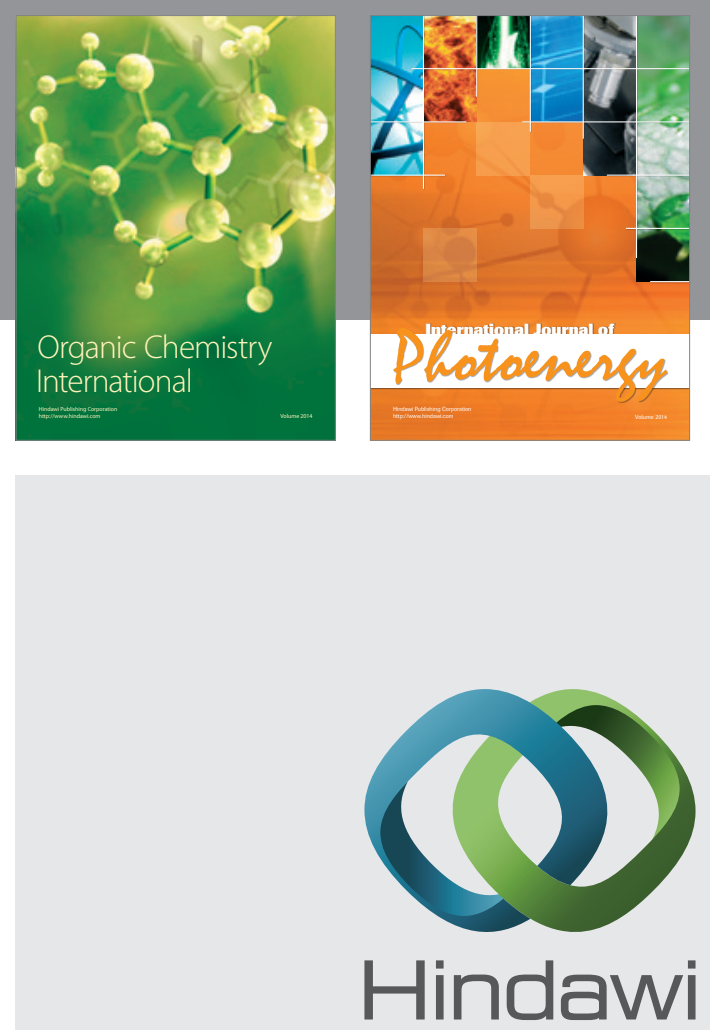

Submit your manuscripts at

http://www.hindawi.com
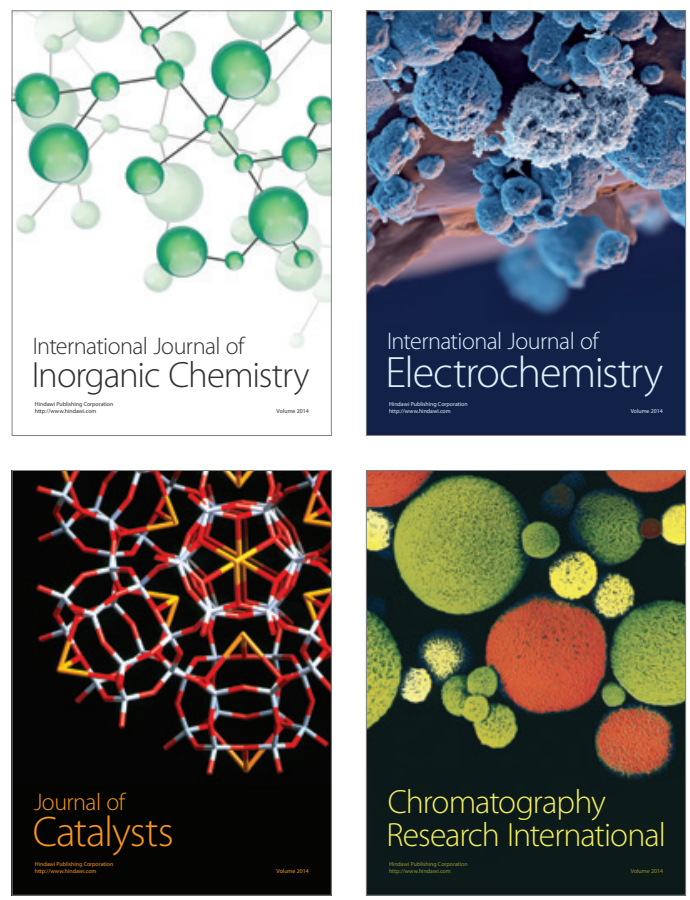
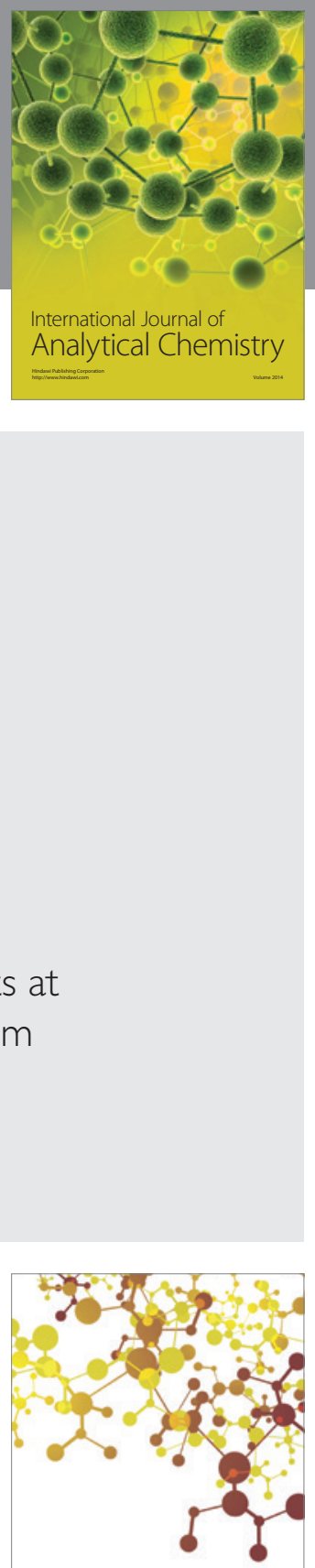

Journal of

Applied Chemistry
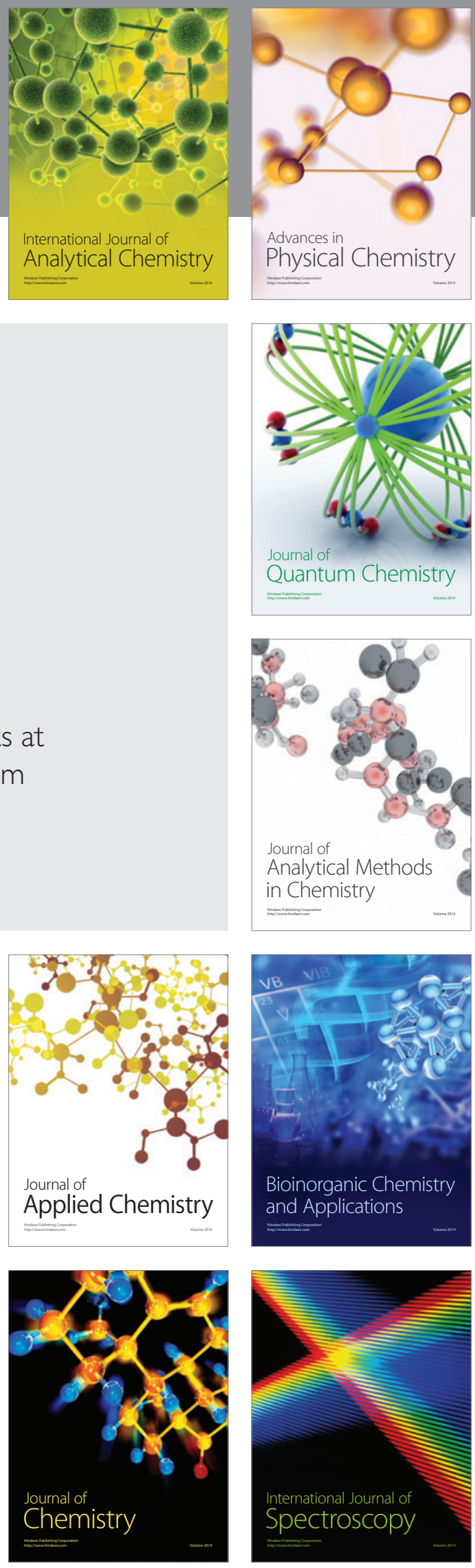